
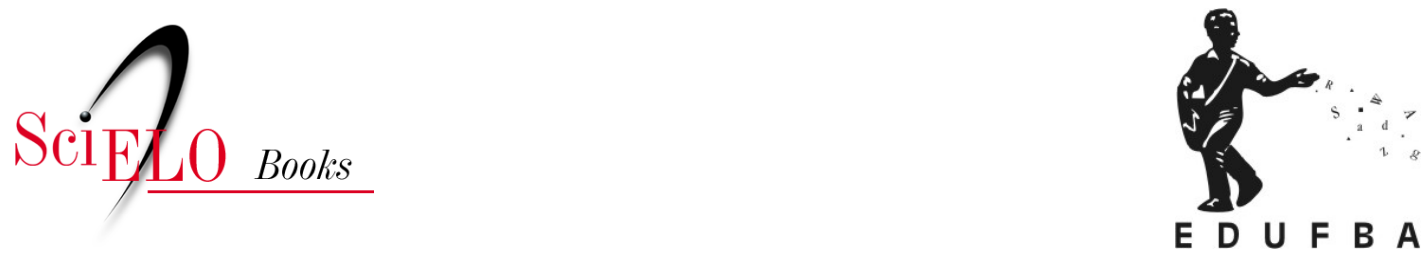

\title{
O Consumo Alimentar como Modo de Perceber no Mundo
}

\author{
Maria Claudia da Veiga Soares Carvalho \\ Fabiana Bom Kraemer \\ Francisco Romão Ferreira \\ Shirley Donizete Prado
}

\section{SciELO Books / SciELO Livros / SciELO Libros}

CARVALHO, M. C. V. S., KRAEMER, F. B., FERREIRA, F. R., and PRADO, S. D. O Consumo Alimentar como Modo de Perceber no Mundo. In: CARVALHO, M. C. V. S., KRAEMER, F. B., FERREIRA, F. R., and PRADO, S. D., eds. Comensalidades em trânsito [online]. Salvador: EDUFBA, 2020, pp. 11-13. Sabor metrópole series, vol. 11. ISBN: 978-65-5630-177-8. http://doi.org/10.7476/9786556301778.0001.

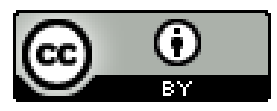

All the contents of this work, except where otherwise noted, is licensed under a Creative Commons Attribution 4.0 International license.

Todo o conteúdo deste trabalho, exceto quando houver ressalva, é publicado sob a licença Creative Commons Atribição 4.0.

Todo el contenido de esta obra, excepto donde se indique lo contrario, está bajo licencia de la licencia Creative Commons Reconocimento 4.0. 


\section{O CONSUMO ALIMENTAR COMO MODO DE PERCEBER NO MUNDO}

Temos o prazer de apresentar esta coletânea que resulta de parceria entre o Laboratório Digital de Educação Alimentar (LADIG’E) do Instituto de Nutrição Josué de Castro da Universidade do Federal do Rio de Janeiro (UFRJ) e o Núcleo de Estudos sobre Cultura e Alimentação (NECTAR) do Instituto de Nutrição da Universidade do Estado do Rio de Janeiro (UERJ).

Corresponde à quarta iniciativa da Rede Ibero-Americana de Pesquisa Qualitativa em Alimentação e Sociedade (REDE NAUS) em matéria de publicações e que, assim, se consolida como uma via através da qual fluem conhecimentos, construindo cooperação acadêmica e firmando a liberdade para criação humana como referência central.

Para chegarmos a esta obra, partimos de uma chamada dirigida aos estudiosos ibero-americanos, à qual obtivemos resposta numericamente muito expressiva e de elevada qualidade analítica. Selecionar os textos que ao final seriam publicados exigiu de nós avaliação bastante criteriosa e de alto refinamento orientada por referenciais centrados no eixo temático teórico e metodológico que definiu o movimento de construção desta linha de debates.

Assim, este encontro de pesquisadores reúne estudos sobre comida, identidades sociais e subjetividades. Um conjunto que consolida esse modo de produzir e divulgar conhecimentos e saberes e que reafirma uma 
liberdade para orientar novas metodologias para novos objetos de análise no campo das Ciências Humanas e Sociais em Alimentação.

Nessa coletânea voltamos nosso olhar para o caráter transitório dos códigos identitários que vamos assumindo em função de determinados consumos. Consumir uma comida ou outra, em grupo ou sozinho, postando nas redes sociais ou não é parte de um modo inerente ao espírito humano de afirmar, e também de negar, identidades. $\mathrm{O}$ consumo na sociedade contemporânea marca um processo que organiza o modo como percebemos o mundo. Se há um fluxo de significação de alimentos como frutas, legumes e verduras como ícones modernos de alimentação saudável, será essa a condição transitória de significação que nos fará sentir mais ou menos saudáveis. A experiência do comer e da comensalidade é inerente ao momento presente no qual os objetos materiais e simbólicos são depositários de narrativas e memórias que flutuam na cultura em aromas, formas, gestos e emoções.

O que nos cabe na organização desta coletânea é favorecer e valorizar espaços para o debate como uma ponte transitória que nos conduz, em meio a essas significações contemporâneas, à construção de identidades singulares imbricadas numa modernidade capitalista e industrial. Nosso objetivo é apresentar análises neste contexto de negociação e trocas simbólicas entre agentes sociais presentes nos campos de pesquisa, oferecendo ao leitor um cardápio de alternativas que desdobram identidades e inventam novos sentidos para a comensalidade contemporânea em diferentes contextos sociais.

A conexão com teorias das Ciências Humanas e Sociais abre novas abordagens críticas e de cunho qualitativo sobre objetos de pesquisa do campo da Saúde. Priorizamos os recursos teóricos que desnaturalizam verdades, desafiando-nos a enfrentar discursos hierarquizados e submissos, e também analisar a pluralidade e criatividade de outros no processo de fluxos transitórios. São criticadas afirmações de identidade como uma essência humana, assim como também a premissa moderna de uma 'autonomia individual' nas escolhas alimentares. $\mathrm{O}$ modo como nós nos percebemos como sujeito desdobra-se em uma existência transitória e plural de um fluxo de acontecimentos. A concepção de identidade não se assemelha ao DNA. Os códigos identitários são efeito de conjunções discursivas que operam uma miríade de significados do universo simbólico de uma cultura ou coletividade. Através da linguagem, os discursos ligam nossa intimidade mais sensível e 
singular, mas em formas transitórias que vão dando sentido de pertencimento às nossas vidas em cada momento.

Assim, dividimos os capítulos em dois momentos segundo a orientação temática: "Cultura e consumo alimentar" com seis capítulos e "Códigos identitários e alimentação" com outros seis. São analisados padrões de comida de verdade e de alimentação saudáveis em práticas discursivas situadas em espaços diversos, desde cozinhas até textos de livros escolares. Alguns estudos identificam o modo como padrões de vida saudável silenciam vozes e produzem violência simbólica. Os textos que selecionamos para leitura buscam refletir alternativas de pertencimento a um tipo de sociedade mais solidária que queremos e precisamos construir.

Maria Claudia da Veiga Soares Carvalho Fabiana Bom Kraemer Francisco Romão Ferreira Shirley Donizete Prado 